Fida J. Adely

\title{
EDUCATING WOMEN FOR DEVELOPMENT: THE ARAB HUMAN DEVELOPMENT REPORT 2005 AND THE PROBLEM WITH WOMEN'S CHOICES
}

The Arab Human Development Report 2005, the fourth in a series that has received much acclaim and stirred much controversy, takes up the issue of women's development in the Arab world. Through a careful reading and analysis of sections of the report that address education and economic participation, this paper offers a critique of the human capabilities framework that frames this report. I highlight critical tensions between the claim that providing education is an essential element of expanding choices and the assumptions embedded in discussions about women and education regarding which choices are acceptable and/or desirable. These tensions point to the persistence of values derived from the mandates of global capital, albeit in the new language of neoliberal choice, revealing that "human development" does not represent a significant departure from earlier conceptualizations of development. I draw on my ethnographic research in Jordan as one example to interrogate such assumptions and to shed light on the ambiguities built into the educational project for young women today.

(C) 2009 Cambridge University Press 0020-7438/09 $\$ 15.00$ 